\title{
Social networks in the non-profit sector: Social support practices
}

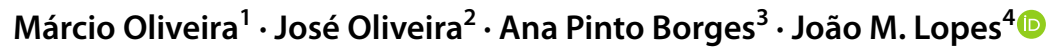

Received: 17 August 2020 / Accepted: 12 March 2021 / Published online: 6 April 2021

(c) The Author(s), under exclusive licence to Springer-Verlag GmbH Germany, part of Springer Nature 2021

\begin{abstract}
This paper aims to analyze the adequacy of social support practices in the nonprofit sector by users and representatives which are part of "Conselho Local de Ação Social (CLAS)" a non-profit organization located in the north of Portugal and focused on the prevention of social exclusion and poverty. A mixed methodological approach was used. A questionnaire was applied to social beneficiaries. To complement the results, interviews with the entities that constitute the executive board of CLAS were conducted. It was possible to perceive the discrepancies on the social support provided and measure the assessment given by the entity responsible for the social network. Consequently, we could conclude that the beneficiaries of the social response under research perceive a low level of social support received, as opposed to the institutions that perceive a high level of social support provided. This difference in support perception is reflected in all the dimensions analyzed. This research supports executors and decision makers responsible for the implementation of local social support policies on the alignment of beneficiaries' expectations as well as contribute on the operation improvement of social networks. As for contributions to the practice, some practical suggestions are advised to social network operators, such as the need for more active listening with feedback for beneficiaries, as well as a set of other measures to be implemented regularly in the medium and long term. Regarding contribution to the theory, it is important to mention that the present research is innovative and original as it contributes to clarify and expand the existing literature on social networks in the tertiary sector, based on the analysis of 5 different dimensions of social support. Furthermore, the authors intend to support the welfare of users of the social network under research by increasing the performance of the social network under analysis.
\end{abstract}

Keywords Network · Social network · Social support · Poverty $\cdot$ Social exclusion · Non-profit sector

João M. Lopes

joao.lopes.1987@hotmail.com

Extended author information available on the last page of the article 


\section{Introduction}

Following globalization and the emergence of modern societies, social relations were transferred to a wider territory (Rodrigues et al., 2017). In this context, each social group, or local community, will appropriate itself in different ways on the elaboration of its social networks and collective identities. Nowadays, the transformations on the social grid can be observed, with them, family, neighborhood and solidarity dynamics also change, this is reflected in the lack of care on children, elderly people and dependent individuals. As a consequence, the responsibilities are transferred from the family to the government (Salselas, 1999).

The problem of poverty and social exclusion has been a recurring issue in public debate for some time (Vasconcelos, 2011). With the recent economic crisis caused by covid 19 pandemic it is possible to identify new forms and dimensions of poverty. Societies around the world, with emphasis to the European Union have been aging. As such, programs and policies that foster social support to the non-profit sector are important to support families. Generally, social support, is a problem identified in the minority communities with low income that may have a reduced formal support (Iris et al., 2014; Williams \& Dilworth-Anderson, 2002).

Social support can be defined in terms of existence, or, by the quantity of social relationships in general, or, referring to a particular marital, friendship or organizational relationships. Occasionally, social support is also defined and measured in terms of the structures of individual's social relationships. However, social support is, in most situations, defined in terms of the functional content of relationships, covering the degree of affective-emotional or instrumental involvement, help or information (Ornelas, 1994).

Following the implementation of a social network program, it is possible to affirm that a large part of the success in the reduction or elimination of poverty and social exclusion depends on the effective management of the local social networks (Vasconcelos, 2011). For the present research, we consider networks as structures interdependent organizations, which involve various nonprofit organizations (O'Toole, 1997), as well as individuals who compose them, and who are expected to play an active role as actors in the change process that intends to be implemented. The social network program emerged in Portugal after the approval of Ministers Council decree No. 197/97 from November $18^{\text {th }}$, which became part of a new generation of social policies closely associated to social rights and social inclusion of groups and communities more vulnerable to the risk of social exclusion. By promoting the construction of integrated multidimensional plans with a territorial base, this program favors the articulation and adaptation of national policies to local problems. Being so, it is possible to affirm that organizations are increasingly connected in a network with increasing interest of academics in researching public policies and networks in the non-profit sector (Edelenbos \& Klijn, 2007; Kapucu, 2006; Lambright et al., 2010; Musso et al., 2006).

The social network program encourages the mobilization and coordination of extended partnerships with the participation of the targeted recipients of social intervention projects based on a logic of empowerment. The platform for this 
program, starts with the local network structures that already exist, such as the II Program to fight poverty and the Social Guaranteed Minimum Income, currently known as Social Insertion Income (RMI). Currently, this action model has also been adopted by other sectors of intervention such as the Commission for Protection of Children and Youth in Danger or the Municipal Council of Education. With the implementation of the social network program, a set of social policies aimed to the social inclusion of the most vulnerable groups and communities in risk of social exclusion become effective. Commonly, networks are focused on policies that include multiple reciprocal exchanges. Thus, each member of the network depends on the resources that other members have (Guadalupe, 2016). For this author, the resource pool produces a form of benefit for both. In this sense, network relations should be seen as win-win. Usually, the organizations that incorporate the network cover different sectors of activity and may include informal and formal ties (Agranoff \& McGuire, 1999; Lambright et al., 2010).

However, the context of poor living conditions and the need to increase effectiveness and efficiency of social responses can lead to practices within the social network able to adapt to new times. Within the scope of social network action plans, internal documents such as the social diagnosis or strategic intervention plans should be prepared considering the resources and availability of each social network, the main strategic axes and other dimensions of the action as well as the evaluation of the social support services carried out by social network partners or by the executive board, commonly, this evaluation extends to the opinion of the beneficiaries of social responses. Being so, this research aims to verify which dimensions are most relevant for the users pursuing social support practices provided by the social network as well as the variables that positively affect these dimensions. The perception of the quality of work developed by the social network from the represented entities that constitute the board of CLAS was also analyzed.

Although the research exhibits as a limitation the non-possibility of generalization, the choice of this municipality is concentrated on the fact that it presents its main socioeconomic and demographic indices in line with what is observed in most of the Portuguese territory in the last decade: unemployment increase, prevalence of precarious employment, low wages and low qualifications; a decrease on the indicators concerning economically active population with a consequent increase on the rate of dependent population, an increment both in immigration and population aging.

In this research, practical and theoretical implications are discussed, allowing to check if there is a discrepancy in the perception of social support received and provided as well as what is the assessment attributed to the performance of the social network. This research also intends to contribute with suggestions for the implementation of worthy social support practices within the social network. Since the existing literature on social networks in the non-profit sector is scarce, we intend to contribute to its evolution and clarification. Being so, we consider the present research to be innovative and original, in addition to the contributions mentioned, it uses a differentiating methodology from which it was possible perceived in the literature review. 
The structure of this research starts with a reflection on the theme under research, followed by the literature review where the role of the networks, social network and the role of the social network aiming policies for social inclusion is reviewed. Next, the research methodology is presented followed by the discussion of results. The research ends with the presentation of the conclusions, practical implications, limitations of the research and future lines of investigation.

\section{Literature review}

\subsection{Social support}

When taking a narrower view of social support, the literature is extent to point out some of the basic arguments associated to this area of knowledge, such arguments are mostly related to the nature of social support, its benefits and visibility.

Social support is the awareness or experience that one is cared for, revered, and part of a mutually supportive social network, that may endure benefits to mental and physical health (Taylor, 2011). Social support may also be understood as a social psychological concept that "addresses the mechanisms and processes through which interpersonal relationships protect and help people in their day-to-day lives" (Trepte \& Scharkow, 2016). Social support is often associated to positive health outcomes, one explanation for these health benefits is that social support shields individuals against life stress, the presence of social support reminders reduce both psychological and physiological responses to threat (Hornstein \& Eisenberger, 2017). In times of difficulty, social support may be granted trough interpersonal relationships in the form of hands-on or emotional support (Zee et al., 2020).

Furthermore, Feeney and Collins (2015) suggested that social support can play a different role by enabling individuals to succeed through adversity and stress and secure life's opportunities beyond adversity. Social support binds are undoubtedly advantageous in times of stress, positive results derive mostly by helping individuals to control their emotional responses in stressful circumstances (Taylor, 2011). Other advantages that can be connected to social support are the prevention of associations with fear and the learned fears that people acquire during their lifetime, consequently reducing threat-related stress (Hornstein \& Eisenberger, 2017).

When considering on how social support is handled, it is established that it can be perceived as social support or received social support. In this context, perceived support describes the availability of a social bond, on the other hand, received support describes whether and how this bond was recently triggered (Trepte et al., 2018).

Receiving social support may result on costs and benefits for recipients (Zee et al., 2020), when an individual assists another and such action results on tangible or emotional benefits, and the beneficial outcomes are well described and documented, under some conditions providing social support confers the same benefits as receiving them (Taylor, 2011). In such environment, one should consider that social support only occurs when the potential recipient knows that the provider (i.e., the one giving support) can deliver adequate support, and when the receiver of support is willing to agree on its disclosure (Trepte et al., 2018). 
Social support can be delivered or obtained throughout visible or invisible actions. Visibility refers to the amount of notice that recipients acknowledge that support has been given or comprehend that there is an intention to provide it (Bolger et al., 2000).

According to Bolger and Amarel (2007), previous research suggested that visible social support may involve emotional costs. A supportive act is most effective when it is supported by the recipients' awareness or with the awareness, but in subtlety manner that receiver do not interpret it as supportive act.

It is clear that support visibility does not have the same impact on all recipients, motivations may play a key factor on the visibility outcome. For Zee et al. (2018), such dissimilarities emphasize the necessity to adapt the support to match recipients' motivational distresses. Providers should give the proper visible and invisible support to recipients, enhancing the benefits of support interactions, subsequently nurturing the relationship quality.

Under certain circumstances social support may have negative or embarrassing consequences to recipients (i.e. uncovered poverty resulted from the covid 19 pandemic). Zee et al. (2018), advocates that one form of bypassing these negative effects is to provide support in an 'invisible' way whereby recipients do not interpret the supportive act. Although the importance to provide the correct type of support, there is always the possibility that recipients have particular needs that may be addressed within multiple types of support in distinct environments (Zee et al., 2020).

\subsection{Social networks and networks}

When connections are created, a large horizon of possibilities is opened, such connections can become partnerships, exchanges, friendship, affections, new values and forms of coexistence, knowledge creation, learning, support, dialogues, participation, mobilization, strength politics, achievements amongst others (Castells, 2005). Systems, structures, organizational designs, characterized by a large number and diversity of elements are always considered networks when a conducting wire keeps them connected. Although dispersed, these networks can envisage some connections between them. In the industrial society, the work processes were well represented by the metaphor of the machine (or the mechanism), now the design of networks takes on a preponderant place in the imagination of post-industrial society (Benko \& Lipietz, 1994).

Thus, the concept of "network" has been gaining importance in the manner that today's societies are organized. As such, it is difficult to discern the content of the term due to the different meanings and domains on which it is used: technological, economic, social and cultural; or even the phenomena associated with it (transport, production, business, terrorism, kinship, neighborhood, among others). However, in the genesis of the word we can find the idea of a set of intertwined lines, web or set of points linked together. For Castells and Himanen (2002), a network is a set of interconnected nodules, on the other hand, some networks are open structures capable of expanding unlimitedly and integrating new nodules that can communicate 
within the network, as long as they share the same communication codes. According to the same author, a network is "the absence of a center, replaced by nodules and connections with a variable intensity and geometry between them". In this context, the collaborative interpersonal ties established in the networks effectively help as a social channel through where knowledge and information flow smoothly, improving the integration and coordination of fragmented organizational activities (Atouba \& Shumate, 2020; Bixler \& Springer, 2018; McPherson et al., 2001).

Being so, the scope of approaches developed by social sciences, the notion that everyday life is organized around different networks and the interactions established throughout are increasingly emphasized (Castells \& Himanen, 2002). These interactions tend to originate identity processes in the personal, social, professional, institutional or even territorial sphere (Castells \& Himanen, 2002). Therefore, when we replace the constituent points of the networks by people, families, social groups, communities, institutions or other community actors it is possible to perceive a huge source of possible relationships or interconnections which characterize the dynamics on which current communities tend to be governed. Thus, social networks can also be understood as systems of ties uniting social actors.

Commonly, a non-profit social network attracts actors with similar objectives which facilitates interceptions between them. This phenomenon is called "homophily" (McPherson et al., 2001). The homophily is a feature of non-profit social networks. Homophily is beneficial for actors participating in social networks as it facilitates the communication of tacit knowledge and more sensitive information that companies generally do not want to provide as it can be potentially problematic. Normally, these actors have homogeneous opinions, capacities and views. In this way, actors are opened to rely on the information generated by the social network. Characteristics such as trust, solidarity, reciprocity and cohesion are part of nonprofit social networks (Atouba \& Shumate, 2020; Bixler \& Springer, 2018; McPherson et al., 2001).

It is possible that social networks amongst members of non-profit organizations to be directly translated into effective and transparent non-profit partnerships, since their interpersonal trust may not be similar or transformed into interorganizational trust, consequently social networks amongst members of non-profit organizations may not result in effective and transparent non-profit partnerships (Atouba \& Shumate, 2020; Doney \& Cannon, 1997; Zaheer et al., 1998). Social networks that fall into the non-profit sector may take different forms according to the type of ties and the type of social actors involved. It is important to distinguish primary social networks composed by natural sets of individuals interacting with each other and according to the criteria and personal affinity outside the institutional framework such as affective bonds, as opposed, to secondary social networks composed by sets of people brought together through a function within an institutional structured and formal framework.

Non-profit social network managers are constantly encouraged to invest to understand the dynamics in networks and their donors in order to provide useful knowledge to the strategy they should adopt (AbouAssi \& Tschirhart, 2018). To achieve impact on social performance, these social networks should have partnerships with governmental organizations and profit organizations (Choi et al., 2018). 


\subsection{The social network within the scope of policies for social inclusion}

In Portugal and throughout the European Union for the past two decades the welfare paradigm has gradually given way to new social orientations and policies. These active social policies aim to promote processes for social inclusion, these policies bring together most of the conditions to strengthen the multidimensional character to be applied to policies to combat the phenomena of poverty and social exclusion. Social policies comprise the mobilization of civil society and the community to strengthen the dynamism of intervention on their own social problems as they privilege new levels of action closer to the causes of problems and their solutions in a clear strategy to territorialize the action (Castro \& Gonçalves, 2002).

A social network program encompasses the objectives, principles, action methodology, expected results and their impacts. Local partnership structures of this program are embodied by the local social action councils (CLAS) and parish social commissions (CSF), such local entities constitute themselves the platforms for planning and coordinating social intervention on municipality and parish level respectively. This program gives an important and central role to the municipalities as these bodies are chaired by the president of the board and parish councils respectively.

CLAS have some common characteristics in its functioning / organization. It is constituted by the following bodies: plenary, the executive board and thematic working groups. CSF's are structures of close partnership and knowhow experts on the problems of poverty and social exclusion from a micro perspective level. The existence of supra municipality platforms as a form of organization of the territorial network is the equivalent to NUT III and serves to fill the space for articulation and planning at supra municipality level.

Within the scope of the work carried out by the social network struggle against poverty and social exclusion, it is also important to mention the role of local social development contracts (CLDS). These are privileged instruments for intervention by the networks and represent integrated multisectoral projects based on contracting between local entities which aim to fight persistent poverty and social exclusion in more depressed territories. Priority areas of intervention can be unemployment, parental intervention, training and qualification either for family or the community and institutions as well as information or accessibility.

Social networks are also an instrument for operationalizing the national action plan for inclusion (PNAI), which represents a commitment of the Portuguese Government with the European Union to promote inclusion in Europe. To achieve such duty, this plan promotes the integration of local objectives, national priorities and policies and measures on their planning instruments, enabling greater coherence and territorial coordination of measures at national level.

The social network of the municipality of Oliveira do Bairro is composed by an executive board, a local council for social action and some thematic groups. Thematic groups are working groups organized according to the intervention issues and priorities. These groups are involved in the development of one or more projects / actions in the area of their work theme.

The executive board is the operational body of the social network. It consists of technicians made from the entities represented for the purpose. This body has the 
following competences: 1) stimulate specific actions of the social network; 2) organize, facilitate CLAS meetings and execute its deliberations; 3) issue opinions on the county's applications to be submitted; 4) operationalize, monitor and evaluate the intervention; 5) distribute the results of the work carried out by the social network; 5) update the social diagnosis; prepare the social development plan and the respective action plans; 6) manage the information system. The executive board is composed by the following entities: i) Câmara Municipal de Oliveira do Bairro (Oliveira do Bairro city council); Segurança Social - Serviço Local de Oliveira do Bairro (Social security—delegation in Oliveira do Bairro); ii) Solsil—Associação de Solidariedade do Silveiro (Solidarity association); iii) Junta de Freguesia de Oliveira do Bairro (Parish Council of Oliveira do Bairro); iv) Centro de Saúde de Oliveira do Bairro (Oliveira do Bairro Health Center); v) Agrupamento de Escolas de Oliveira do Bairro (Oliveira do Bairro School Group); vi) ABC - Associação de Beneficência e Cultura de Bustos, Centro Social de Oiã (Bustos and Oiã beneficiary and social center).

CLAS is the plenary decision-making body and is represented by one individual designated by each of the entities that are part of CLAS. This body is composed by the members listed in Table 1 .

\section{Methodology}

The present research follows a mixed methodology. Despite having two approaches with antagonistic particularities, when combined they may complement the results. The use of mixed methods is adequate for the present research as its foundation is the evolution of the field under research. Being so, we intend

Table 1 CLAS composition in the municipality of Oliveira do Bairro

\begin{tabular}{ll}
\hline Type of Entity & Entities \\
\hline Institutional & $\begin{array}{l}\text { Câmara Municipal de Oliveira do Bairro, Junta de Freguesia Oliveira do Bairro, } \\
\text { Junta de Freguesia de Oiã, União de Freguesias de Bustos, Troviscal e Mamar- } \\
\text { rosa, Junta de Freguesia da Palhaça }\end{array}$ \\
$\begin{array}{c}\text { Private Social Soli- } \\
\text { darity Institutions }\end{array}$ & $\begin{array}{l}\text { Casa do Povo da Mamarrosa, ABC - Associação de Beneficência e Cultura de } \\
\text { Bustos, Centro Social de Oiã, Santa Casa da Misericórdia de Oliveira do Bairro, } \\
\text { SOLSIL - Associação de Solidariedade Social do Silveiro, AMPER - Asso- } \\
\text { ciação Amigos de Perrães, Só Bustos, Centro Ambiente para Todos, Centro } \\
\text { Social S. Pedro da Palhaça, Associação de Solidariedade Social "O Recanto da } \\
\text { Natureza”, Infantário Frei Gil; } \\
\text { Centro Regional da Segurança Social de Oliveira do Bairro, IEFP - Centro de } \\
\text { Emprego de Águeda, Centro de Saúde de Oliveira do Bairro, IRS - Instituto } \\
\text { de Reinserção Social, Gabinete de Consulta Jurídica de Oliveira do Bairro, } \\
\text { IDT - Instituto da Droga e Toxicodependência, Guarda Nacional Republicana, } \\
\text { Agrupamento Vertical de Escolas de Oliveira do Bairro, Agrupamento Vertical } \\
\text { de Escolas de Oiã, Escola Secundária de Oliveira do Bairro } \\
\text { ACIB - Associação Comercial Industrial da Bairrada, À Medida - Associação } \\
\text { de Formação Profissional, ACAI - Associação Concelhia para a Integração, } \\
\text { Gabinete de Consulta Jurídica de Oliveira do Bairro, Grupo Cáritas do Trovis- } \\
\text { cal, Grupo Cáritas da Palhaça, Grupo Cáritas de Oiã, Grupo Cáritas de Bustos, } \\
\text { Sociedade S. Vicente de Paulo }\end{array}$ \\
\hline Associations & \\
\hline
\end{tabular}


to take advantage of the strengths of each methodology by promoting a multidisciplinary approach amongst researchers (Creswell, 2010; Johnson et al., 2016).

To elaborate the questionnaire, a social support scale was applied and validated as described by Griep et al. (2005). The questionnaire includes 19 questions, divided into 5 dimensions (material, affective, emotional, informative and social interaction), with five levels of response, according to the Likert scale used with the following correspondence: $1=$ Never, $2=$ Rarely, $3=$ Sometimes, $4=$ Almost always and 5=Always. Although anonymous, 12 questions of an identifiable nature of the respondent were added to the questionnaire bearing in mind statistical treatment of data. The questionnaires were administered in person and individually to the respondents by the staff from the social institutions designated for this accomplishment during the months of December 2019 and January 2020.

In the data analysis, descriptive statistics were considered in a first phase. In a second phase, an exploratory factor analysis and confirmatory analysis were carried out to assess the main social dimensions considering all the tests necessary to confirm the adequacy of the analysis. In a third phase, and, to understand the determinants of each factor, the Mann-Whitney and Kruskal-Wallis nonparametric tests were applied. Analysis were performed using SPSS application (version 21). Finally, Pearson's correlation was performed to understand if the impacts of the variables on the dimensions had a positive or negative effect.

On a subsequent phase, the representatives of the seven institutions that constitute the executive board of CLAS in the municipality of Oliveira do Bairro were interviewed (Câmara Municipal de Oliveira do Bairro (Oliveira do Bairro city council); Segurança Social - Serviço Local de Oliveira do Bairro (Social security—delegation in Oliveira do Bairro); Solsil—Associação de Solidariedade do Silveiro (Solidarity association); Junta de Freguesia de Oliveira do Bairro (Parish Council of Oliveira do Bairro); Centro de Saúde de Oliveira do Bairro (Oliveira do Bairro Health Center); Agrupamento de Escolas de Oliveira do Bairro (Oliveira do Bairro School Group); ABC - Associação de Beneficência e Cultura de Bustos, Centro Social de Oiã (Bustos and Oiã beneficiary and social center). This set of interviews aimed to assess the perception of those responsible for the performance of this social network. The semi-structured interview guide was built using the contributions from Vasconcelos (2011). The questions referred in the script were open question and subjected to validation prior to their application. The semi-structured interviews were conducted individually and in person to the institutional representatives who have a seat in the meetings of the executive board of CLAS. Having collected the questionnaires from the seven institutions, the sample considered is equal to the universe of the research. During the qualitative phase, care was taken to encourage respondents to reveal their own interpretations. This condition is essential to the success of a case research and may even indicate new sources of evidence.

The contents comparison from the interviews with the representatives of the executive management of CLAS with the feedback provided in the responses from the social beneficiaries, whereby the same items of analysis were addressed, allowed the authors to determine the discrepancy between the perceptions on the support given and received. 
The questions used in the interview covered the following subjects: 1) reasons for poverty and social exclusion; 2) obstacles to reduce or eliminate poverty and social exclusion in the context of the intervention of the social network; 3) types of entities with greater responsibilities on disrupt poverty or social exclusion; 4) most positive aspects in the intervention of the social network in the struggle against poverty and social exclusion; 5) most negative aspects in the intervention of the social network in the struggle against poverty and social exclusion; 6) evaluation on the work these entities carry out throughout the social network in the struggle against poverty and social exclusion.

\section{Analysis and discussion of results}

\subsection{Quantitative analysis}

The research sample comprises 102 respondents from a universe of 350 users as described in Table 2. On the exhibited data, we can observe that $59.8 \%$, are male and aging over 40 years. Regarding marital status, $67.6 \%$ were unmarried (which includes singles, widowers and divorcees), $71.5 \%$ had a basic level of education and 90.2\% had a lower income level (approximately the national minimum wage). On the number of close people, $40.2 \%$ indicated that they had between 1 or 2 relatives or close friends, more than half, $56.9 \%$, did not live alone, all referred to be volunteers and $69.6 \%$ indicated as having low religious activity (once or none). Finally, regarding health status, $59.8 \%$ reported as having one or two chronic diseases, $44.1 \%$ reported a "bad" state of health and $79.4 \%$ expressed as having no mental disorders.

Table 3 describes the five dimensions under research (Material Dimension, Affective Dimension, Emotional Dimension, Information Dimension, Positive Social Interaction Dimension), according to the social support scale originally applied in Medical Outcomes Study adapted to Portuguese language and validated according to the model derived from Griep et al. (2005). It seems that no item of the dimensions has an average greater than three (which corresponds to the frequency level "sometimes"), which leads us to conclude that the level of social support is low in this sample.

From the material dimension, it appears that $31.4 \%$ stated that "almost always" and "always" have someone to take him / her to the doctor. On the contrary, $47.1 \%$ never count on anyone to help him / her with daily tasks, if he / she becomes ill. In the affective dimension, $23.5 \%$ indicated that they nearly always have someone who shows love and affection for themselves and makes them feel wanted. However, $40.2 \%$ stated that they never count on someone who loves them and makes them feel wanted.

In the emotional dimension, $21.6 \%$ showed that they almost always have someone who will listen when they need to speak. In a negative way, it is noteworthy that $46.1 \%$ never count on someone to share their most intimate concerns and fears. In the information dimension, $22.5 \%$ stated that they almost always count on someone to give them information to help them understand a certain situation, on the opposite side, $37.3 \%$ never count on someone to listen and advise. In the dimension 


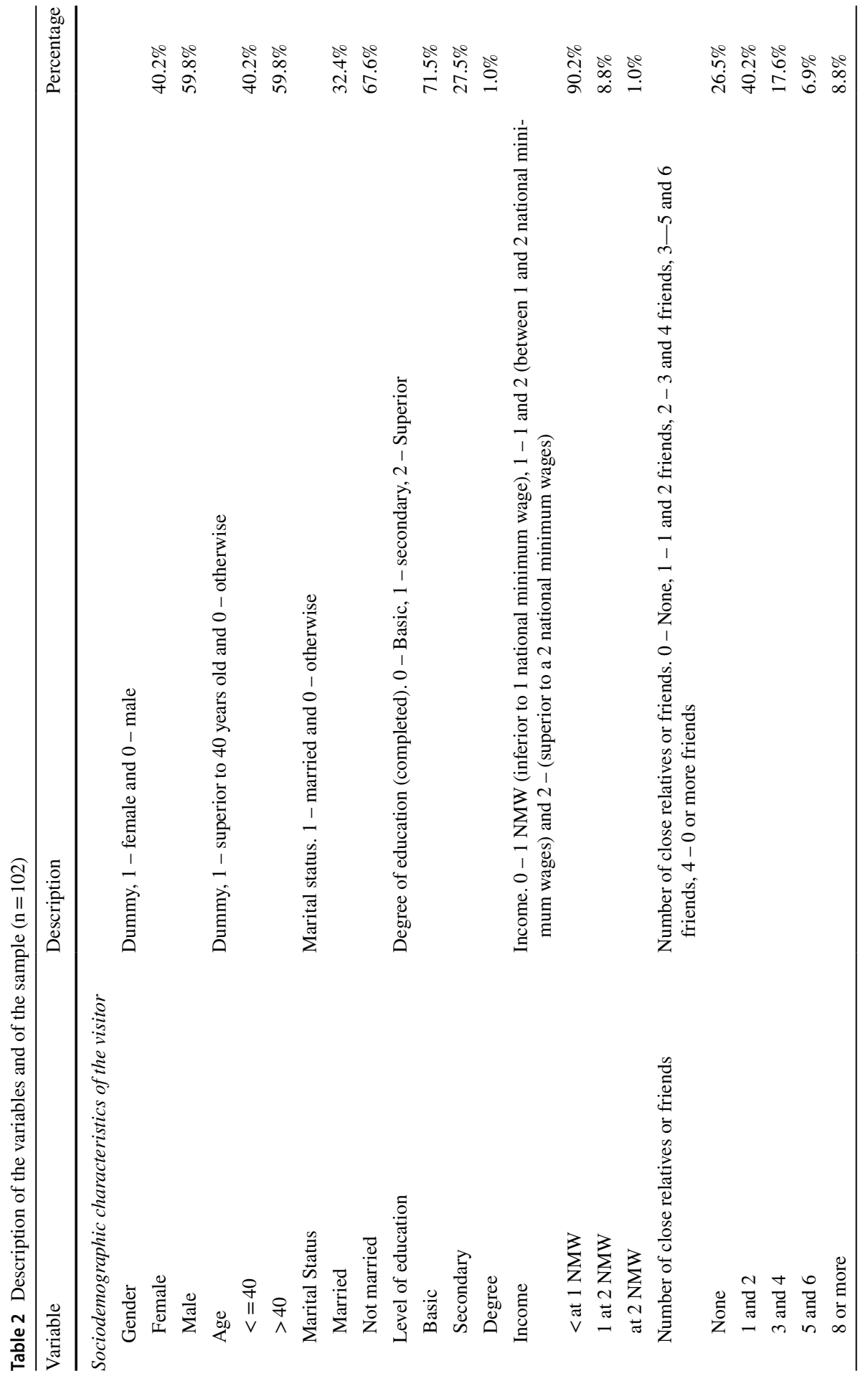




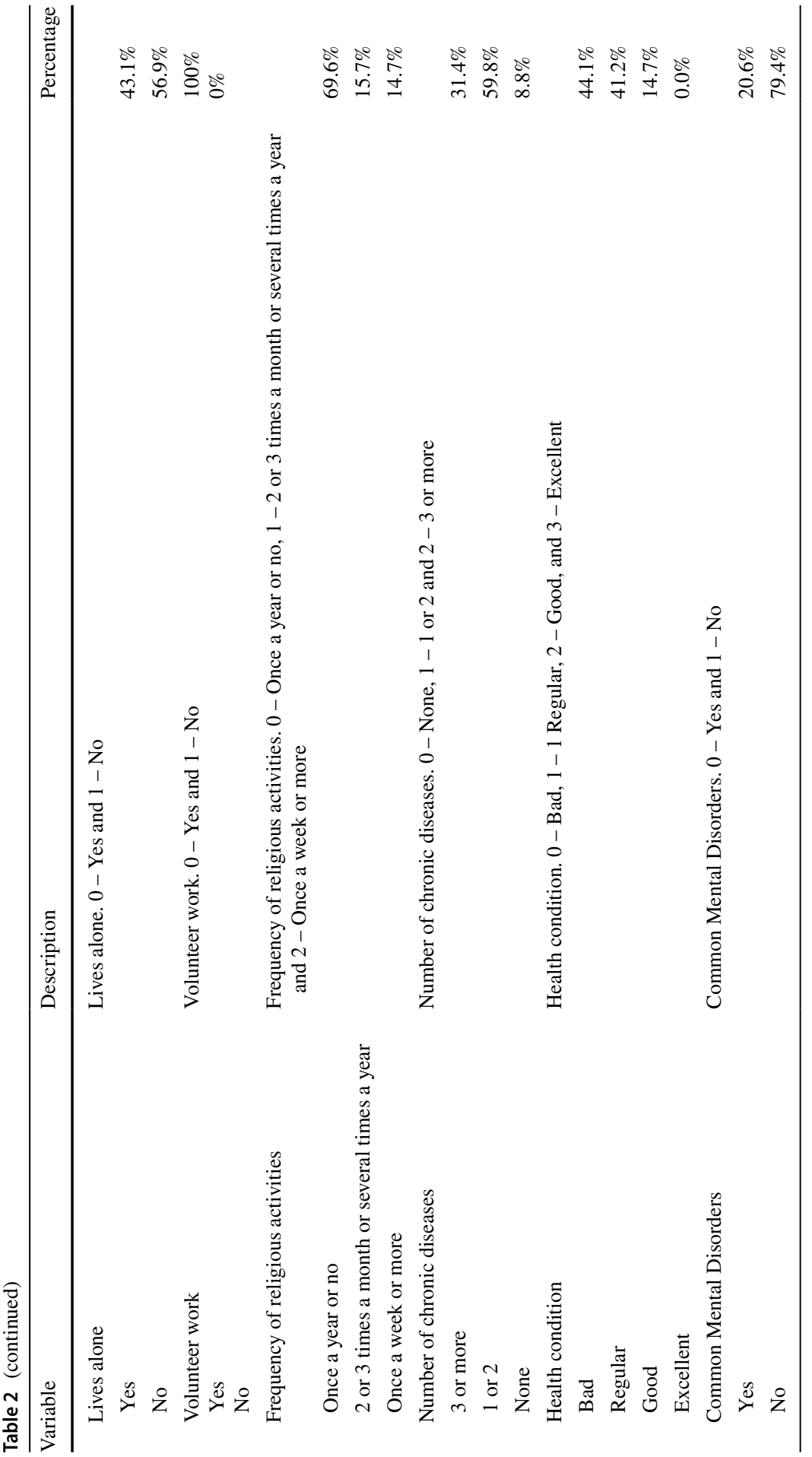




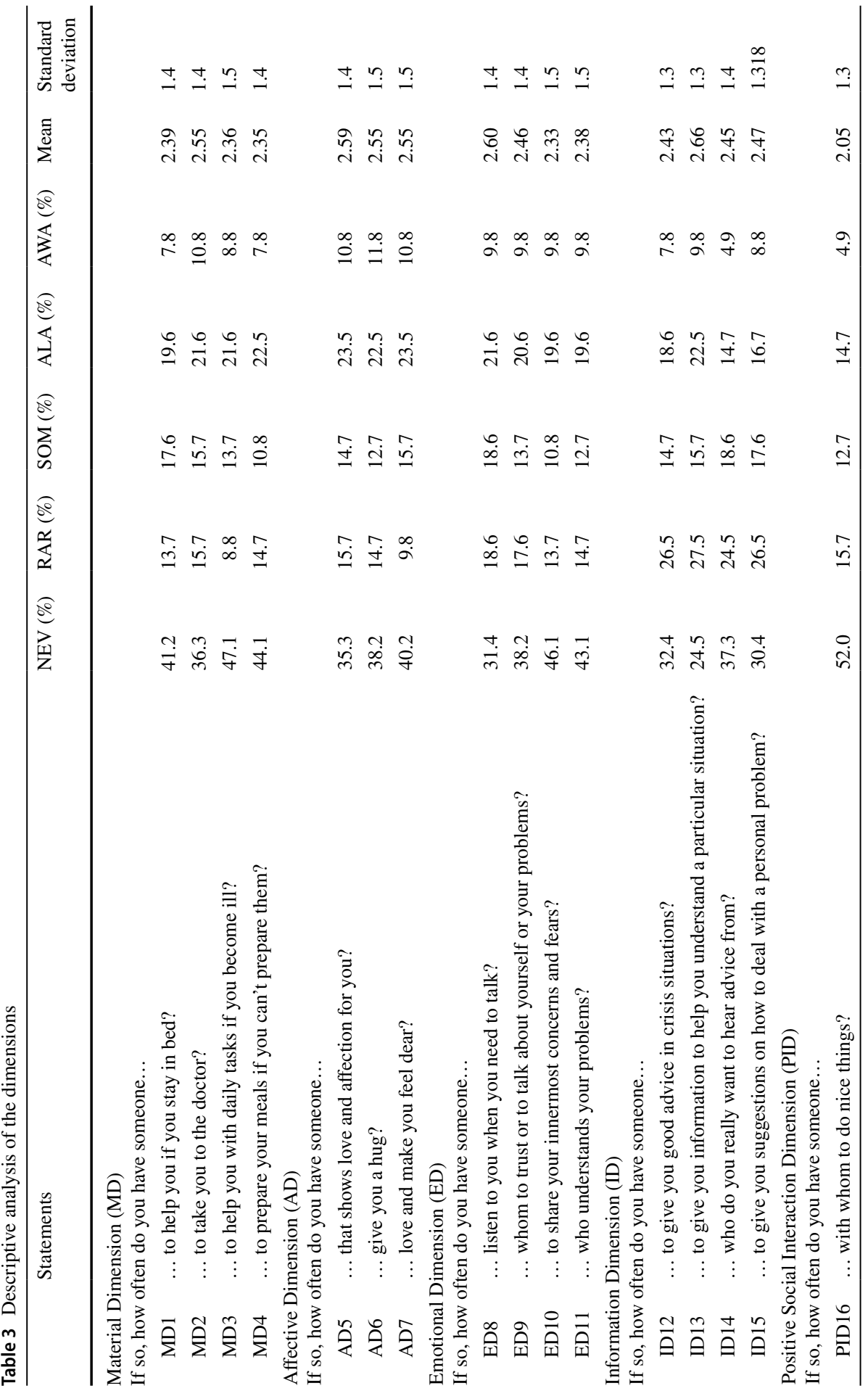




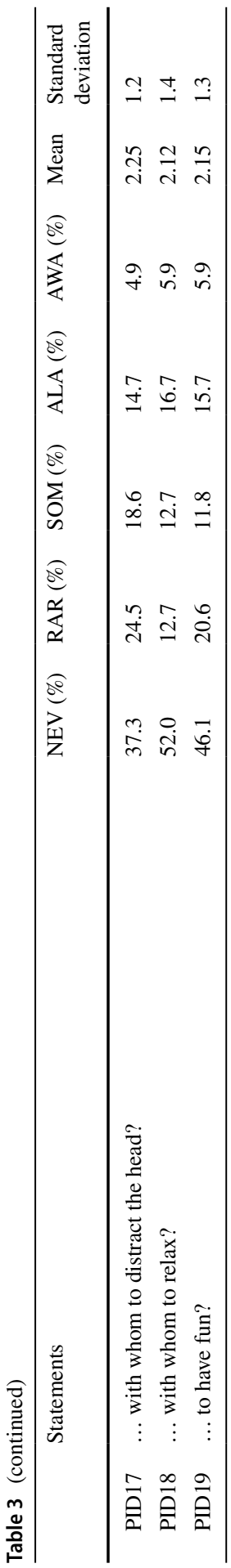


of positive social interaction, only $16.7 \%$ highlighted that they almost always have someone to relax with and $52.0 \%$ mentioned that they never count on someone to do pleasant things and to relax.

All the results present in the different dimensions differ from the ones obtained by Griep et al. (2005), where several items are presented with an average higher than $4=$ almost always. These results are mostly in line with those verified by the authors Sherbourne and Stewart (1991) and can be explained by the characteristics of the respondents, as we have $91.2 \%$ of respondents with a chronic disease, $44.1 \%$ selfreported a "bad" state of health. and $20.6 \%$ with mental illness. Our results indicate that the level of support is low, and the consequences can be very serious in this community, contributing to the increase in psycho-logical disorders and stress (Folkman, 2013; Hobfoll, 1989) unhappiness, and so on. This situation, not yet reversing, could further aggravate the mental health of the elderly in times of COVID-19 (ElZoghby et al., 2020; Saltzman et al., 2020).

Notes: $\mathrm{NEV}=$ never; RAR = Rarely; $\mathrm{SOM}=$ sometimes; $\mathrm{ALA}=$ almost always; $\mathrm{AWA}=$ always.

\subsubsection{Construct validity}

In the application of the foremost analysis component of all items of the five dimensions described above, three distinct constructs resulted, which explain $89.752 \%$ of the total variance of the items (Table 4). It was found that no item carried more than one construct, reinforcing the independence of each one. The data obtained from the pre-tests $(\mathrm{KMO}=0.912$ and Bartlett $\chi 2=3945.797 ; \mathrm{p}=0.000)$, the correlations between the items indicate that the factor analysis is adequate to perform the analysis. The reliability coefficient (or consistency) was also analyzed using the Cronbach Alpha for the three constructs, values greater than 0.6 were obtained which is why they are considered acceptable (Cortina, 1993).

Factor 1 explains $79.493 \%$ of the variation and is the most important factor. This construct carried items related to the information and emotional dimensions. Factor 2 presents $5.903 \%$ of the variance and carried the items related to the affective and material part. Factor 3 only carried items related to positive social interaction. These two constructs have less relative relevance than the first.

The results of the confirmatory analysis show that the measurement model fits well with the data (Hair et al. 2010). Convergent validity was studied by calculating the construct's reliability (CR) and the extracted average variance (AVE). The AVE and composite reliability (CR) values are above the proposed threshold (Fornell \& Larcker, 1981). The psychometric properties of the measurement factors used in the estimation of the model are satisfactory as indicated by the values of CR $(>0.7)$ and AVE (>0.6) (Bagozzi \& Yi, 1988).

In summary, four dimensions were obtained, again, this result differs from the ones obtained by Griep et al. (2005), and are closer to the ones presented by the authors Sherbourne and Stewart (1991). Empirical evidence of the multidimensionality of social support scales have not shown uniform results, which occasionally can be explained by the high correlation between the intensities of scales (e.g. Berkman et al. (2000); Cohen et al. (1985); Griep et al. (2005)). 


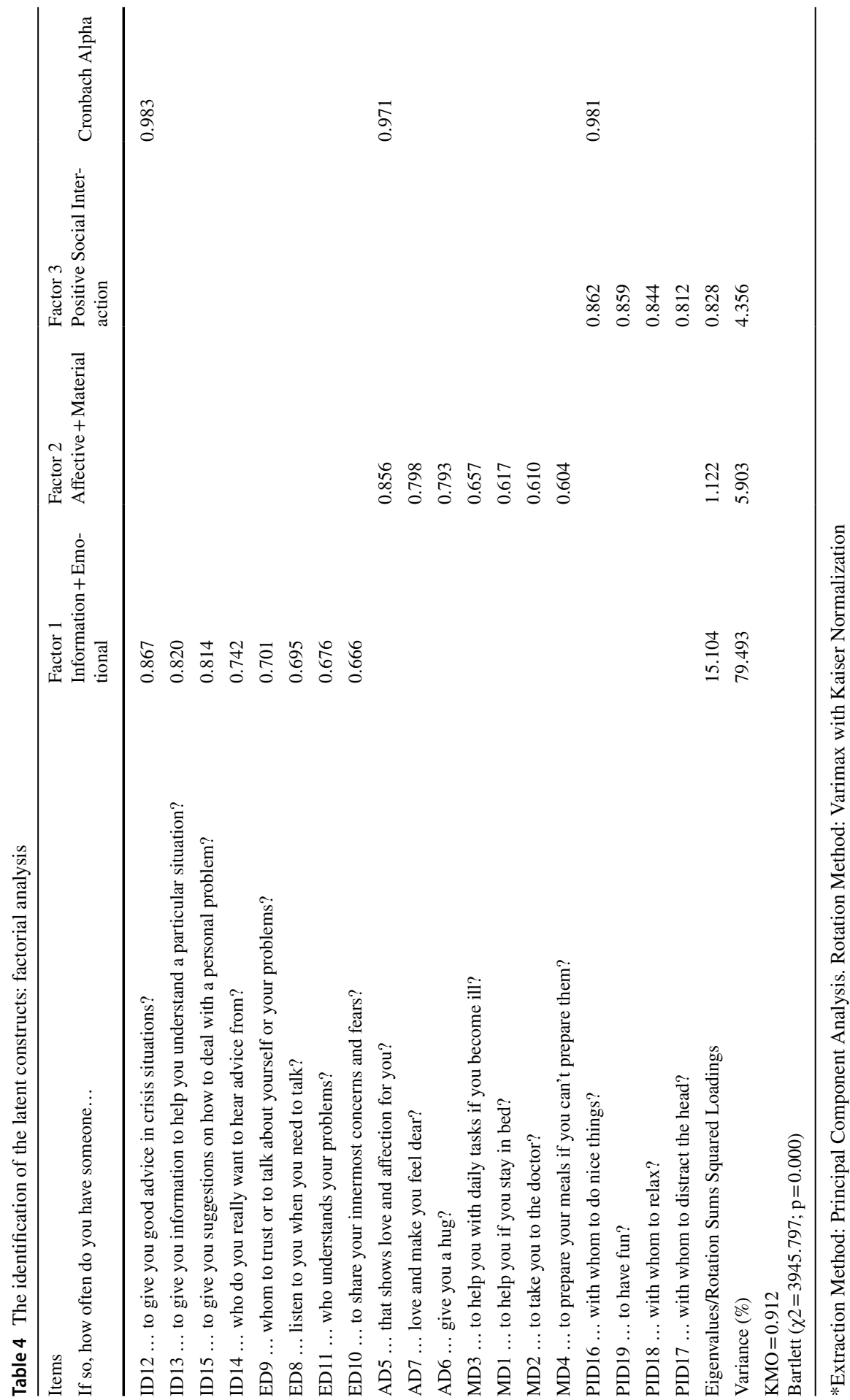




\subsubsection{Hypothesis test}

For the hypothesis test, Kruskal-Wallis test or Mann-Whitney non-parametric tests were applied (Table 5). Through the application of these tests it is possible to observe the main determinants of each of the factors.

"Factor 1 is influenced by marital status and the number of close family members and friends. Specifically, being married and having close family and friends contributed positively to factor 1 (Bowling, 1997)."

"Factor 2 is positively influenced by marital status (being married in relation to those who are not married), income (a high level of income in relation to low income), the number of close family members and friends (a high number of family members and friends in relation to those who do not have), live alone (do not live alone in relation to those who live alone), and for mental disorders (not having mental disorders in relation to those who have) (Helminen et al., 1995)".

"Factor 3 is influenced by gender, age, income, living alone, frequency of religious activity, and health status. Specifically, it is positively influenced by gender (being a woman in relation to men), income (a high level of income in relation to the low level of income) and living alone (not living alone in relation to those who live alone). On the other hand, this factor is negatively influenced by age (there is a measure that increases the age in relation to the younger ones) and the frequency of religious activities (the greater number of religious activities in relation to those who are not in the habit of this type of activities) (Bellón Saameño et al., 1996)."

\subsection{Qualitative analysis}

The aim of the qualitative part of this research was acquiring the perception of the members of the executive board of CLAS actions on the role of the Oliveira do Bairro social network. In order to understand the reasons that justify the situations of poverty and social exclusion of people in the municipality of Oliveira do Bairro, respondents were asked to identify the three main reasons for a predetermined list. The following tables summarize the respondents' responses according to the items under research, Table 6 shows the identified reasons.

Hence, it is possible to perceive that low levels of work income (wages) are pointed out by all respondents as one of the main reasons for poverty and social exclusion in Oliveira do Bairro. Subsequently, the precarious job that was mentioned by four respondents. As for other reply reasons, six more arise, but with less expression than the previous ones. This type of results is in line with Smeeding (2005), for this author poverty may be the result of low wages or social benefits. Moreover, to Laderchi et al. (2003) apart from other perceptions, financial capability is what triggers poverty.

In order to understand which are the obstacles to the reduce or eliminate poverty and social exclusion in the municipality within the scope of the social network, respondents were asked to identify the three main obstacles, Table 7 presents the most perceived obstacles. 


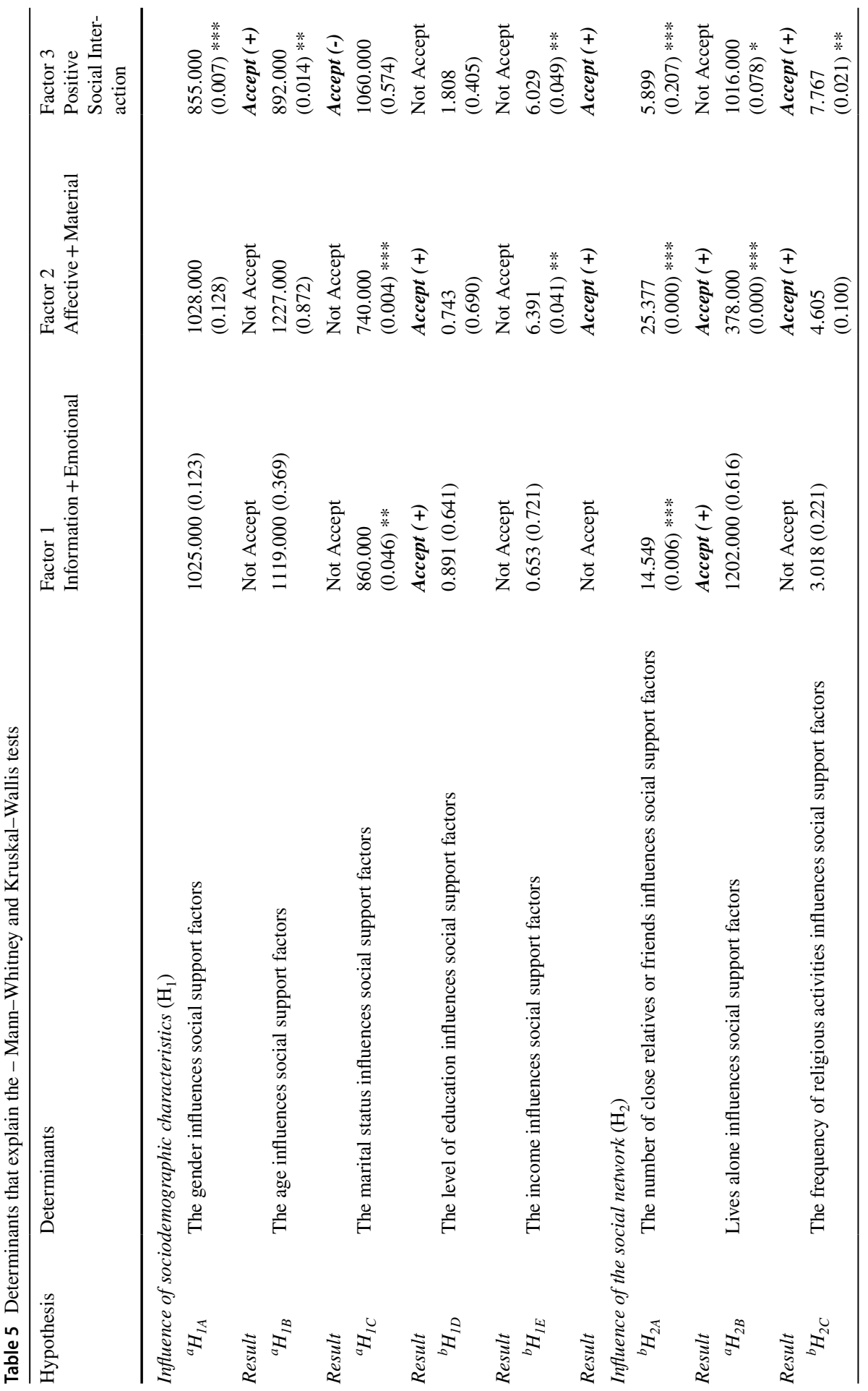




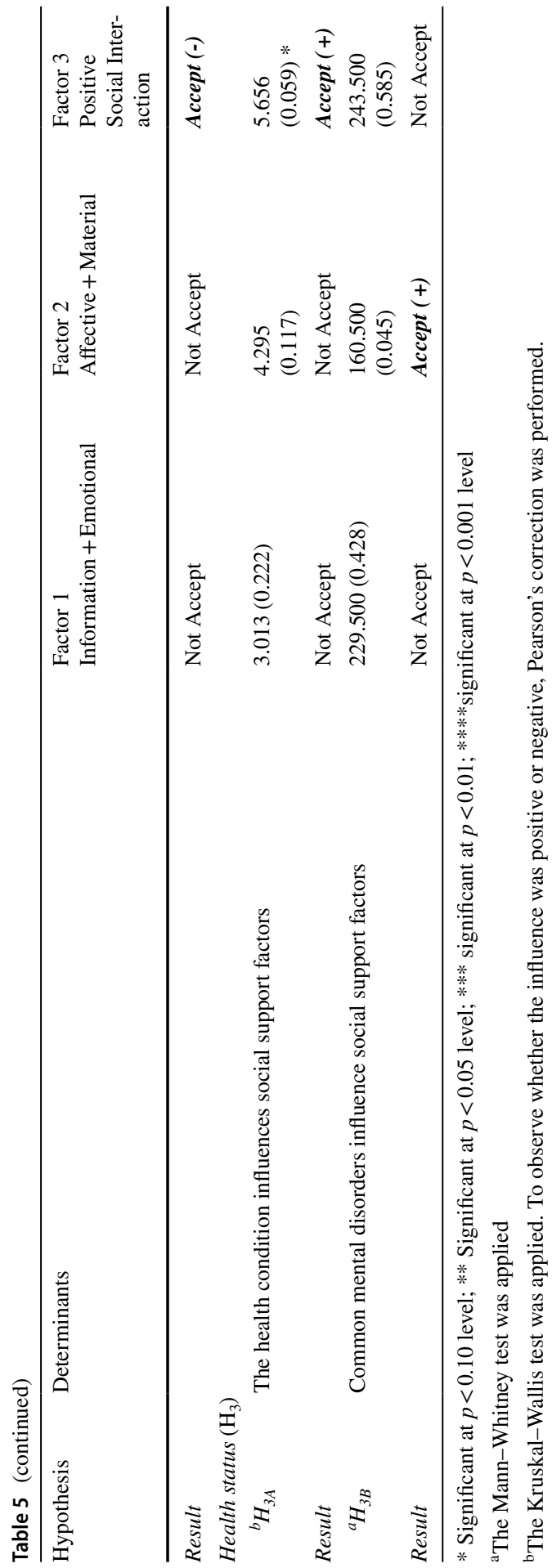


Table 6 Reasons for poverty and social exclusion

\begin{tabular}{llc}
\hline Reason & $\begin{array}{c}\text { Absolute } \\
\text { Frequency }\end{array}$ & $\begin{array}{c}\text { Relative } \\
\text { Fre- } \\
\text { quency }\end{array}$ \\
\hline $\begin{array}{l}\text { Low levels of labor income (wages) } \\
\text { Precarious employment }\end{array}$ & 7 & $33.4 \%$ \\
$\begin{array}{l}\text { Existence of an active population with little education and qualifications } \\
\text { Failure, absenteeism and early abandonment of the education system }\end{array}$ & 2 & $19 \%$ \\
$\begin{array}{l}\text { Weakening of family and social ties, interpersonal networks and traditional } \\
\text { solidarity (family, neighbors and community) }\end{array}$ & 2 & $9.5 \%$ \\
$\begin{array}{l}\text { Personal attributes, social maladjustment or incapacity and unwillingness of } \\
\text { individuals in situations of social exclusion to participate in social life }\end{array}$ & 2 & $9.5 \%$ \\
$\begin{array}{l}\text { Dysfunctionality and family breakdown } \\
\text { Inherited poverty / Phenomenon of intergenerational transmission of poverty }\end{array}$ & 1 & $9.5 \%$ \\
\hline
\end{tabular}

Following this line of tough, it is possible to point out that from the perspective of almost all respondents (6 out of 7 ) the main obstacle for reduction or elimination of poverty and social exclusion is the prolonged dependence on social policy measures and other support from the government followed by diminutive participation and intervention from civil society. With some expression, the gap between the qualifications required by the labor market and the qualifications of individuals looking for work is also mentioned as an obstacle. Other obstacles are mentioned, but without the same expression as the previous ones. For Ghai (2003) the obstacle may not be the shortage of resources but the absence of government capacity to implement and coordinate programs to contribute for social exclusion and poverty reduction. On the other hand, families may suffer from poverty and social exclusion especially if they are low-skilled (Köhler et al., 2009).

In order to understand the respondents' individual opinion on which entity intervention provides a disruption from a situation of poverty or social exclusion, it was questioned which type of entities have more responsibilities.

Table 8 exhibits the answers for this question according to a predetermined list of types of entities.

In such way, it is noticeable that the respondents consider by a large majority that the networks of family relationships and solidarity are the main responsible for disruption situations of poverty or social exclusion. Also mentioned are the different structures of local partnerships and non-governmental organizations or private institutions of social solidarity, but with less influence.

In order to understand the most positive aspects of the social network's intervention in struggling against poverty and social exclusion in the municipality of Oliveira do Bairro, respondents were asked to indicate the three aspects they consider as having the most impact. Table 9 presents the aspects indicated by the respondents, according to a list of hypotheses of predetermined response. 


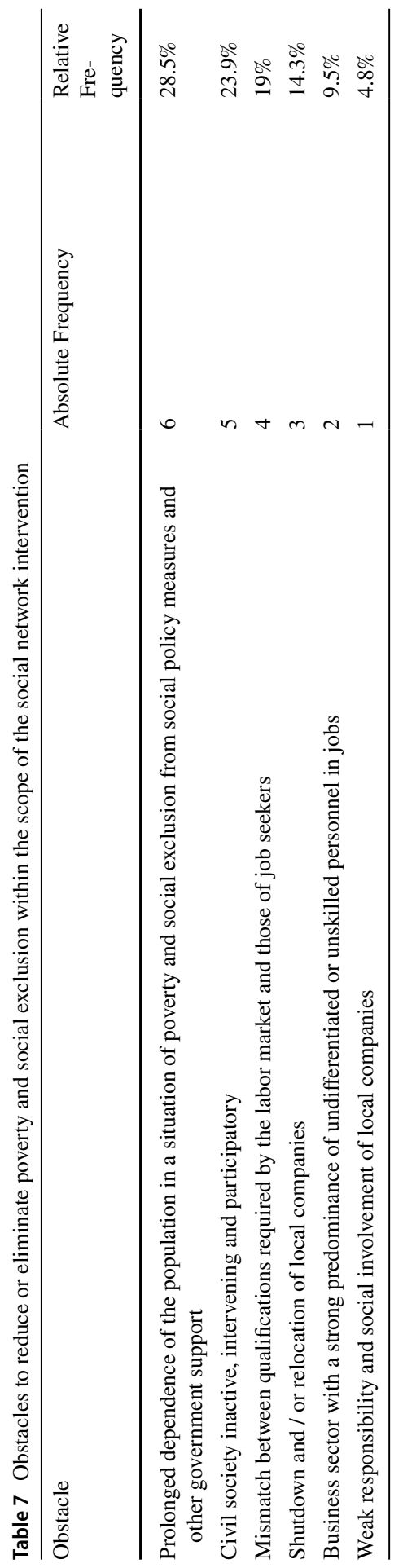


Table 8 Typology of entities with greater responsibilities in breaking the situation of poverty or social exclusion

\begin{tabular}{lll}
\hline Entities & $\begin{array}{l}\text { Absolute } \\
\text { Frequency }\end{array}$ & $\begin{array}{l}\text { Relative } \\
\text { Fre- } \\
\text { quency }\end{array}$ \\
\hline Networks of family relations and solidarity & 4 & $57.2 \%$ \\
Different local partnership structures & 2 & $28.5 \%$ \\
Non-governmental organizations or Private & 1 & $14.3 \%$ \\
Social Solidarity Institutions & & \\
\hline
\end{tabular}

Being so, it is possible to perceive that in the opinion of the respondents the most positive aspect pointed out by all respondents is the coordination of the intervention that avoids piecemeal interventions and overlapping of actions. The construction of updated diagnoses is also mentioned by a significant number of respondents as being one of the most positive aspects of the social network in view of the stated objective.

The success of social network also involves a number of aspects, referred as positive for the social network, but whose mention is less prevalent such as the investment in training and education, which would guarantee positive results and reduce poverty (Feigl et al., 2013).

In order to understand the most negative aspects of the social network's intervention in fighting poverty and social exclusion in the municipality of Oliveira do Bairro, respondents were asked to indicate the three aspects they consider as having the most impact. Table 10 shows the aspects indicated by the respondents according to a list of hypotheses of predetermined response.

As such, it is possible to perceive that the insufficient participation of people in situations of poverty and social exclusion is mentioned by all respondents as the most negative aspect in the intervention of the social network in the combat against poverty and social exclusion. The difficulties in mobilizing business for this fight is also enunciated as one of the most negative aspects, 5 responses. The scarce information and visibility given to the intervention of the social network and the legislative framework of the social network also deserve particular mention as being negative aspects with considerable impact.

Finally, respondents were asked about to classify the work developed by the social network in combating poverty and social exclusion. Out of the 7 respondents, 5 rated this work as very good, while 2 respondents consider this work as being good. In other words, all respondents have a very positive opinion regarding this assessment.

\section{Conclusions and future research}

The importance of social networks in the non-profit sector has become increasingly relevant in the current world. Therefore, cohesion and solidarity have emerged by different actors (individual or collective) in the social economy (Donati, 2011; Majetic et al. 2019). In this context, the present research aims to analyze the suitability of social support practices within a social network of users. The most relevant 


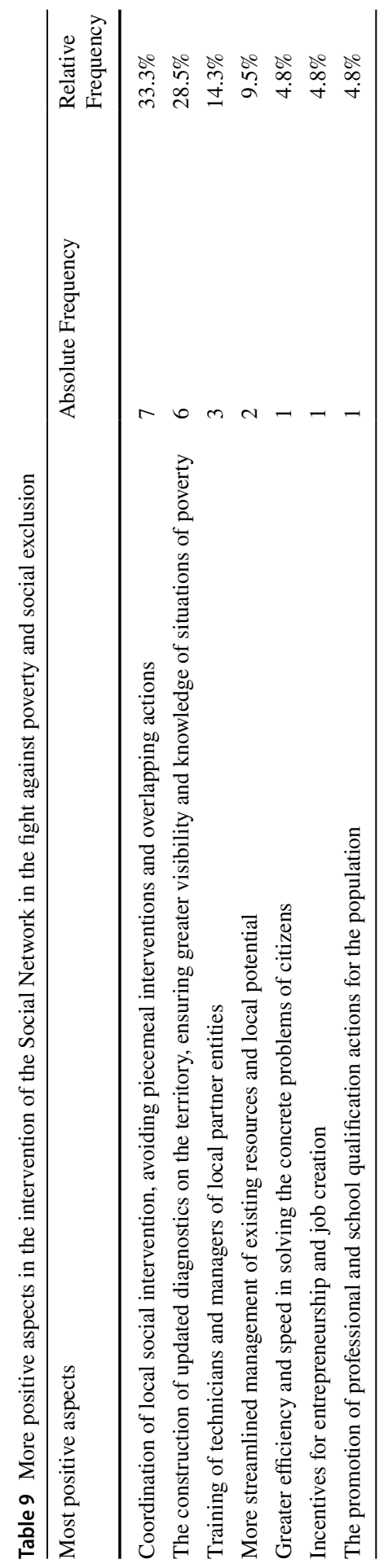


Table 10 Most negative aspects in the intervention of the Social Network in the fight against poverty and social exclusion

\begin{tabular}{lcc}
\hline Most negative aspects & $\begin{array}{l}\text { Absolute } \\
\text { Frequency }\end{array}$ & $\begin{array}{l}\text { Relative } \\
\text { Fre- } \\
\text { quency }\end{array}$ \\
\hline $\begin{array}{l}\text { Insufficient participation of people in situations of poverty and social exclusion } \\
\text { Difficulties in promoting social involvement of local companies }\end{array}$ & 7 & $33.3 \%$ \\
Scarcity of information and visibility given to the intervention of the Social & 4 & $23.9 \%$ \\
$\quad$ Network & 4 & $19 \%$ \\
Social Network's legislative framework restricts the innovative spirit of civil & 4 & $19 \%$ \\
$\quad$ society, contributing to reduce its participation & 1 & $4.8 \%$ \\
Weak involvement of partner entities & & \\
\hline
\end{tabular}

dimensions for users were verified as well as the variables that positively affect such dimensions. The perception of the quality of work available throughout the entities that make up the executive board of the CLAS social network was also corroborated.

Regarding the 5 dimensions under analysis in the present research (Material Dimension, Affective Dimension, Emotional Dimension, Information Dimension, Positive Social Interaction Dimension), the results suggest that users consider the level of social support to be low and insufficient and still have a long path for development. Information and Emotional dimensions are those that users consider as most relevant. The variables that positively affect Information and Emotional dimensions are marital status, what is in line with indicates by Qian et al. (2019), more specifically being married and having family and close friends. Being so, it is suggested that the social network under analysis in the research should first raise awareness amongst its technicians and operational staff on this reality. Users value listening when they need to talk, having someone they can trust to talk about themselves or their problems, as well as having someone to share their most intimate concerns and fears with who understands their problems (Qian et al., 2019). Users also feel the need to receive good advice regarding crisis situations and personal problems, they need help to understand a particular situation and need advice.

Subsequently, we suggest some actions that can be implemented in the short term on the social network. The social network can organize meetings in groups presential or digital so the users can interact, share experiences, and live together, thus dissipating some of the needs that were previously identified. The social network can also have some technical staff who can be on social networks and can talk to their users as well as having a service line where users can call and talk to someone. Sometimes, many users feel isolated as family members and friends live far from users or even living close but do not have enough time to share with their family and friends (Piraino et al., 2017), what affects them psychologically (Ha et al., 2018; Scharlach, 2017). This situation is the result of a society that has more and more tasks in its work just as there is a wide range of cultural offerings and technological distractions to which society channels most of the time.

The Information and Emotional dimensions were evaluated positively by its users (Qian et al., 2019), is it recommended to check the measures that can be 
implemented in order to improve the performance of the social network in the other dimensions. The measures must be introduced in a phased manner and not all at once so that technicians are able to adapt gradually, thus achieving the expected results. We also suggest that the social network use this questionnaire periodically, for example, every 6 months, in order to check its performance in the different dimensions that are improving. Thus, they can see the effect of possible measures that they may implement.

In the medium and long term, it is necessary for the various public entities to act in different contexts and through different initiatives, in order to improve the Material, Affective and Positive Social Interaction dimensions, with the help also of a behavioral change of the beneficiaries. The strategies could be based on the theory of planned behavior (Ajzen, 1985) widely used in fields such as healthcare, advertising, public relations, sport management, sustainability, and others. This theory is based on the following dimensions: attitude, subjective norm, and perceived behavioral control that together influence individual behavior (Ajzen, 1985). In relation to attitude, it is necessary to encourage a change in the perception related to life (Qian et al., 2019). Beneficiaries will not be able to wait for social support to solve all problems, together with the institutions, they so be an agent of change. Possibly this dimension is the most difficult one to impel, but it may be essential to reinforce the area of psychology with the beneficiaries to guarantee the change in behavior. To adapt to the aging process, users have to constantly make psychological and physiological adjustments (Furr et al., 2016). In the case of subjective norm, it will be necessary for public entities to act more closely with society to avoid successive judgments. Further actions reinforcing training and education would benefit on performance change.

These actions allow greater integration of beneficiaries and change in behavior. In relation to perceived behavioral control, beneficiaries cannot constantly perceive that it is a "burden" in economic and social terms for society (Villar, 2012). There is a need to recognize that older people are a social asset and that are necessary to support future generations.

Only with dedicated strategies is it possible to minimize the consequences of social support not perceived by the beneficiaries. The absence of social support has drastic consequences in society, namely at the economic, social, and health level of the population (Arling, 1987). Such methods would empower society to handle with some stigma and public entities to act more efficiently.

When comparing the responses from the beneficiaries of the social service assistance with the responses from monitors of the social network the result may seem antagonistic. As previously indicated, users perceive a low level of social support received and the institutions responsible for the social network perceive a high level of social support provided to users. Particularly noteworthy is the need for social support that beneficiaries demonstrate in the dimension of positive social interaction, as it is the one with the lowest values and where, in contrast, the institutions under research, the greatest potential for providing support. Some of the motives responsible to understand the discrepancy on the judgement of the given support can be related to a proper meeting with the provider, or, if the correct support was given by the right person (Taylor, 2011). 
Despite this discrepancy in perception between support received and provided, entities with seats in the executive board of the CLAS rate the work carried out by the social network as "very good". For this body, the main reasons for poverty and social exclusion are the low levels of income (wages) and the main obstacle to reduce or eliminate poverty or social exclusion is the prolonged dependence of the population under these circumstances on measures of social policy and other government support (Koehler, 2017). Also for this body, the entities best placed to combat this fight with poverty and social exclusion are the networks of family relationships and solidarity; the coordination of local social intervention, avoiding piecemeal interventions and overlapping actions is seen as the most positive aspect of network intervention in combating poverty and social exclusion and the insufficient participation or involvement of people in situations of poverty and social exclusion is seen as the most negative aspect of this networking. In the present research, it was not mentioned that the frustrated perspective of social support by the beneficiaries in contrast to the perception of high social support provided by the institutions, may be one of the reasons for failure, an obstacle or a negative aspect of the social work carried out in the network. According to Streeter and Franklin (1992), support networks have played an important role in the practice of social work, and their evaluation is important.

The present research is original and contributes to clarify and increase the existing literature on social networks in the non-profit sector, which is still small and needs further investigation. Discrepancies were found in the results between the adequacy of social support practices within a Social Network by users and by representatives of the entities that make up the CLAS executive group of the social network. Several suggestions for implementation were given enabling social support practices to meet the expectations of users. The authors expect to contribute to increase the welfare of users of the social network under research. Furthermore, the obtained results also expose a clear representation on how social support could reduce psychological and physiological stress (Hornstein \& Eisenberger, 2017).

This research has some limitations, the results presented are specific to the specific social network under analysis. The research covers only five dimensions and only the entities that constitute the CLAS social network executive board were interviewed. It was not possible to interview all the entities that make up the social network, if possible, the qualitative results could be different,

As for future lines of research, the same questionnaire could be applied to all social networks in the non-profit sector in Portugal, later the research could be replicated in different countries comparing the results. Verify if there are other dimensions that users consider important to analyze and that are not included in the present research. Users could also be interviewed to understand the reasons for the results of this research. We leave some research questions to explore in future studies: Using the different demographic variables as a dependent variable, do the results of the five dimensions under research change? What are the sources of income from non-profit social networks? How can non-profit social networks raise extra income? What are the factors that are taken into account when recruiting technicians and operational and volunteers for the non-profit social network? What variables do non-profit social networks consider when defining how much 
time technicians and / or operational and / or volunteers have to spend with each user.

\section{References}

AbouAssi, K., \& Tschirhart, M. (2018). Organizational response to changing demands: Predicting behavior in donor networks. Public Administration Review, 78(1), 126-136. https://doi.org/10.1111/puar. 12786

Agranoff, R., \& McGuire, M. (1999). Managing in network settings. Review of Policy Research, 16(1), 18-41. https://doi.org/10.1111/j.1541-1338.1999.tb00839.x

Ajzen, I. (1985). From intentions to actions: A theory of planned behavior. In J. Kuhl \& J. Beckmann (Eds.), Action control: From cognition to behavior (pp. 11-39). Springer Berlin Heidelberg.

Arling, G. (1987). Strain, social support, and distress in old age. Journal of Gerontology, 42(1), 107-113. https://doi.org/10.1093/geronj/42.1.107

Atouba, Y. C., \& Shumate, M. D. (2020). Meeting the challenge of effectiveness in nonprofit partnerships: Examining the roles of partner selection, trust, and communication. VOLUNTAS: International Journal of Voluntary and Nonprofit Organizations, 31(2), 301-315. https://doi.org/10.1007/ s11266-019-00143-2

Bagozzi, R. P., \& Yi, Y. (1988). On the evaluation of structural equation models. Journal of the Academy of Marketing Science, 16(1), 74-94. https://doi.org/10.1007/bf02723327

Bellón Saameño, J. A., Delgado Sánchez, A., Luna del Castillo, Jd. D., \& Lardelli Claret, P. (1996). Validez y fiabilidad del cuestionario de apoyo social funcional Duke-UNC-11. Atención Primaria, 18(4), 153-163.

Benko, G., \& Lipietz, A. (1994). O novo debate regional: posições em confronto. Celta Editora LDA.

Berkman, L. F., Glass, T., Brissette, I., \& Seeman, T. E. (2000). From social integration to health: Durkheim in the new millennium. Social Science and Medicine, 51(6), 843-857. https://doi.org/10. 1016/S0277-9536(00)00065-4

Bixler, R. P., \& Springer, D. W. 2018. Nonprofit Social Capital as an Indicator of a Healthy Nonprofit Sector. Nonprofit Policy Forum, 9(3). https://doi.org/10.1515/npf-2018-0017.

Bolger, N., \& Amarel, D. (2007). Effects of social support visibility on adjustment to stress: Experimental evidence. Journal of Personality and Social Psychology, 92(3), 458-475. https://doi.org/10.1037/ 0022-3514.92.3.458

Bolger, N., Zuckerman, A., \& Kessler, R. C. (2000). Invisible support and adjustment to stress. Journal of Personality and Social Psychology, 79(6), 953-961. https://doi.org/10.1037/0022-3514.79.6.953

Bowling, A. (1997). Measuring social networks and social support. In A. Bowling (Ed.), Measuring health: A review of quality of life measurements scales (2nd ed., pp. 91-109). Open University Press.

Castells, M. (2005). A Era da Informação: Economia, Sociedade e Cultura, A Sociedade em Rede (2nd ed.). Fundação Calouste Gulbenkian.

Castells, M., \& Himanen, P. (2002). The information society and the welfare state: The finnish model. Oxford University Press.

Castro, J. L., \& Gonçalves, A. 2002. A rede social e o desenvolvimento local: parcerias sociais e planeamento participado. Cidades, Comunidades e Territórios (4).

Choi, Y., Chang, S., Choi, J., \& Seong, Y. 2018. The partnership network scopes of social enterprises and their social value creation. International Journal of Entrepreneurship, 22(1).

Cohen, S., Mermelstein, R., Kamarck, T., \& Hoberman, H. M. (1985). Measuring the functional components of social support. In I. G. Sarason \& B. R. Sarason (Eds.), Social support: Theory, research and applications (pp. 73-94). Springer Netherlands.

Cortina, J. M. (1993). What is coefficient alpha? An examination of theory and applications. Journal of Applied Psychology, 78(1), 98-104. https://doi.org/10.1037/0021-9010.78.1.98

Creswell, J. W. 2010. Mapping the Developing Landscape of Mixed Methods Research. In A. Tashakkori, and C. Teddlie (Eds.), SAGE handbook of mixed methods in social \& behavioral research, Vol. 2: (pp. 45-68). SAGE Publications. 
Donati, P. (2011). Modernization and relational reflexivity. International Review of Sociology, 21(1), 21-39. https://doi.org/10.1080/03906701.2011.544178

Doney, P. M., \& Cannon, J. P. (1997). An Examination of the nature of trust in buyer-seller relationships. Journal of Marketing, 61(2), 35-51. https://doi.org/10.1177/002224299706100203

Edelenbos, J., \& Klijn, E. H. (2007). Trust in complex decision-making networks - A theoretical and empirical exploration. Administration \& Society, 39(1), 25-50. https://doi.org/10.1177/00953 99706294460

El-Zoghby, S. M., Soltan, E. M., \& Salama, H. M. (2020). Impact of the COVID-19 pandemic on mental health and social support among adult egyptians. Journal of Community Health, 45(4), 689-695. https://doi.org/10.1007/s10900-020-00853-5

Feeney, B. C., \& Collins, N. L. (2015). A new look at social support: A theoretical perspective on thriving through relationships. Personality and Social Psychology Review, 19(2), 113-147. https://doi.org/10.1177/1088868314544222

Feigl, G., Hergovich, S., \& Rehm, M. (2013). Beyond GDP: Can We Refocus the Debate? In D. Natali \& B. Vanhercke (Eds.), Social Developments in the European Union 2012 (pp. 63-89). ETUI and European Social Observatory.

Folkman, S. (2013). Stress: Appraisal and Coping. In M. D. Gellman \& J. R. Turner (Eds.), Encyclopedia of behavioral medicine (pp. 1913-1915). Springer New York.

Fornell, C., \& Larcker, D. F. (1981). Evaluating structural equation models with unobservable variables and measurement error. Journal of Marketing Research, 18(1), 39-50. https://doi.org/10. $2307 / 3151312$

Furr, N., O’Keeffe, K., \& Dyer, J. H. 2016. Managing multiparty innovation. Harvard Business Review, 2016 (November).

Ghai, D. (2003). Social security priorities and patterns: A global perspective. SSRN Electronic Journal. https://doi.org/10.2139/ssrn.366081

Griep, R. H., Chor, D., Faerstein, E., Werneck, G. L., \& Lopes, C. S. (2005). Construct validity of the Medical Outcomes Study's social support scale adapted to Portuguese in the Pro-Saude Study. Cadernos de Saúde Pública, 21(3), 703-714. https://doi.org/10.1590/s0102-311×20050003000 04

Guadalupe, S. (2016). Intervenção em rede: serviço social, sistémica e redes de suporte social. Universidade de Coimbra.

Ha, N. H. L., Chong, M. S., Choo, R. W. M., Tam, W. J., \& Yap, P. L. K. (2018). Caregiving burden in foreign domestic workers caring for frail older adults in Singapore. International Psychogeriatrics, 30(8), 1139-1147. https://doi.org/10.1017/S1041610218000200

Hair, J., Anderson, R., Babin, B., \& Black, W. 2010. Multivariate data analysis: A global perspective: NJ.

Helminen, A., Halonen, P., Rankinen, T., Nissinen, A., \& Rauramaa, R. (1995). Validity assessment of a social support index. Scandinavian Journal of Social Medicine, 23(1), 66-74. https://doi.org/10. $1177 / 140349489502300112$

Hobfoll, S. E. (1989). Conservation of resources: A new attempt at conceptualizing stress. American Psychologist, 44(3), 513-524. https://doi.org/10.1037/0003-066X.44.3.513

Hornstein, E. A., \& Eisenberger, N. I. 2017. Unpacking the buffering effect of social support figures: Social support attenuates fear acquisition. PLOS ONE, 12(5). https://doi.org/10.1371/journal.pone. 0175891.

Iris, M., Berman, R. L., \& Stein, S. (2014). Developing a faith-based caregiver support partnership. Journal of Gerontological Social Work, 57(6-7), 728-749. https://doi.org/10.1080/01634372.2014. 898007

Johnson, R. B., Onwuegbuzie, A. J., \& Turner, L. A. (2016). Toward a definition of mixed methods research. Journal of Mixed Methods Research, 1(2), 112-133. https://doi.org/10.1177/1558689806 298224

Kapucu, N. (2006). Interagency communication networks during emergencies - Boundary spanners in multiagency coordination. American Review of Public Administration, 36(2), 207-225. https://doi. org/10.1177/0275074005280605

Koehler, G. (2017). The politics of rights-based, transformative social policy in South and Southeast Asia. International Social Security Review, 70(4), 105-126. https://doi.org/10.1111/issr.12155

Köhler, G., Cali, M., \& Stirbu, M. (2009). Part 1: Regional Overview and Findings, Social Protection in South Asia: A Review: 2-20. UNICEF Regional Office. 
Laderchi, C. R., Saith, R., \& Stewart, F. (2003). Does it matter that we do not agree on the definition of poverty? A comparison of four approaches. Oxford Development Studies, 31(3), 243-274. https:// doi.org/10.1080/1360081032000111698

Lambright, K. T., Mischen, P. A., \& Laramee, C. B. (2010). Building trust in public and nonprofit networks personal, dyadic, and third-party influences. American Review of Public Administration, 40(1), 64-82. https://doi.org/10.1177/0275074008329426

Majetic, F., Makarovic, M., Simlesa, D., \& Golob, T. (2019). Performance of work integration social enterprises in Croatia, Slovenia, and Italian Regions of Lombardy and Trentino. Economics and Sociology, 12(1), 286-301. https://doi.org/10.14254/2071-789x.2019/12-1/17

McPherson, M., Smith-Lovin, L., \& Cook, J. M. (2001). Birds of a feather: Homophily in social networks. Annual Review of Sociology, 27(1), 415-444. https://doi.org/10.1146/annurev.soc.27.1.415

Musso, J. A., Weare, C., Oztas, N., \& Loges, W. E. (2006). Neighborhood governance reform and networks of community power in Los Angeles. American Review of Public Administration, 36(1), 79-97. https://doi.org/10.1177/0275074005282586

O'Toole, L. J. (1997). The implications for democracy in a networked bureaucratic world. Journal of Public Administration Research and Theory, 7(3), 443-459. https://doi.org/10.1093/oxfordjournals. jpart.a024358

Ornelas, J. (1994). Suporte social: Origens, conceitos e áreas de investigação. Análisepsicológica, 12, 333-339.

Piraino, E., Byrne, K., Heckman, G. A., \& Stolee, P. (2017). Caring in the information age: Personal online networks to improve caregiver support. Canadian Geriatrics Journal, 20(2), 85-93. https:// doi.org/10.5770/cgj.20.271

Qian, Z. W., Wan, G. S., Shi, Y. F., \& Huang, G. (2019). From the perspective of ecosystem to discuss the critical factors in the elderly social support. Ekoloji, 28(107), 3127-3131.

Rodrigues, E. V., Samagaio, F., Ferreira, H., Mendes, M. M., \& Januário, S. (2017). A pobreza e a exclusão social: teorias conceitos e políticas sociais em Portugal. Sociologia Revista da Faculdade de Letras da Universidade do Porto, 9, 63-101.

Salselas, T. 1999. Rever, Contextualizar e Requalificar a Acção Social. A Acção Social em Debate, 115-126.

Saltzman, L. Y., Hansel, T. C., \& Bordnick, P. S. (2020). Loneliness, Isolation, and Social Support Factors in Post-COVID-19 Mental Health. Theory, Research, Practice, and Policy. https://doi.org/10. $1037 / \operatorname{tra0000703}$

Scharlach, A. E. (2017). Aging in context: Individual and environmental pathways to aging-friendly communities-The 2015 Matthew A Pollack award lecture. Gerontologist, 57(4), 606-618. https://doi.org/ 10.1093/geront/gnx017

Sherbourne, C. D., \& Stewart, A. L. (1991). The MOS social support survey. Social Science and Medicine, 32(6), 705-714. https://doi.org/10.1016/0277-9536(91)90150-B

Smeeding, T. M. (2005). Public policy, economic inequality, and poverty: The United States in comparative perspective. Social Science Quarterly, 86(s1), 955-983. https://doi.org/10.1111/j.0038-4941. 2005.00331.x

Streeter, C. L., \& Franklin, C. (1992). Defining and measuring social support: Guidelines for social work practitioners. Research on Social Work Practice, 2(1), 81-98. https://doi.org/10.1177/1049731592 00200107

Taylor, S. E. (2011). Social support: A review, The Oxford handbook of health psychology (pp. 189-214). Oxford University Press.

Trepte, S., Masur, P. K., \& Scharkow, M. (2018). Mutual friends' social support and self-disclosure in face-to-face and instant messenger communication. Journal of Social Psychology, 158(4), 430-445. https://doi.org/10.1080/00224545.2017.1398707

Trepte, S., \& Scharkow, M. 2016. Friends and lifesavers: How social capital and social support received in media environments contribute to well-being, The Routledge Handbook of Media Use and WellBeing: International Perspectives on Theory and Research on Positive Media Effects: 304-316: Taylor and Francis.

Vasconcelos, M. (2011). A rede social do concelho de Ovar e a sua percepção do combate à pobreza e exclusão social. Instituto Superior de Ciências Sociais e Políticas.

Villar, F. (2012). Successful ageing and development: The contribution of generativity in older age. Ageing and Society, 32(7), 1087-1105. https://doi.org/10.1017/S0144686X11000973 
Williams, S. W., \& Dilworth-Anderson, P. (2002). Systems of social support in families who care for dependent African American elders. The Gerontologist, 42(2), 224-236. https://doi.org/10.1093/ geront/42.2.224

Zaheer, A., McEvily, B., \& Perrone, V. (1998). Does trust matter? Exploring the effects of interorganizational and interpersonal trust on performance. Organization Science, 9(2), 141-159. https://doi.org/ 10.1287/orsc.9.2.141

Zee, K. S., Bolger, N., \& Higgins, E. T. (2020). Regulatory effectiveness of social support. Journal of Personality and Social Psychology. https://doi.org/10.1037/pspi0000235

Zee, K. S., Cavallo, J. V., Flores, A. J., Bolger, N., \& Higgins, E. T. (2018). Motivation moderates the effects of social support visibility. Journal of Personality and Social Psychology, 114(5), 735-765. https://doi.org/10.1037/pspi0000119s

Publisher's note Springer Nature remains neutral with regard to jurisdictional claims in published maps and institutional affiliations.

\section{Authors and Affiliations}

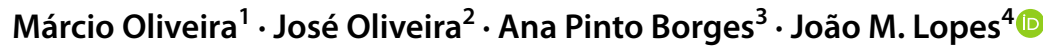

Márcio Oliveira

marciosol@hotmail.com

José Oliveira

jcastroliveira@gmail.com

Ana Pinto Borges

anaborges@isag.pt

1 Polytechnic Institute of Leiria \& NECE - Research Unit in Business Sciences, Rua General Norton de Matos, Apartado, 4133, 2411-901 Leiria, Portugal

2 University of Minho, Largo do Paço, 4704-553 Braga, Portugal

3 ISAG - European Business School and Research Center in Business Sciences and Tourism (CICET - FCVC), Campus de Salazares/Ramalde, Rua dos Salazares 842, 4100-442 Porto, Portugal

4 Miguel Torga Institute of Higher Education \& University of Beira Interior \& NECE - Research Unit in Business Sciences, Largo Cruz de Celas nº1, 3000-132 Coimbra, Portugal 